\title{
TREATMENT OF DIARRHEA-PREDOMINANT IRRITABLE BOWEL SYNDROME WITH MESALAZINE AND/OR SACCHAROMYCES BOULARDII
}

\author{
Mauro BAFUTT01,2, José Roberto de ALMEIDA3, \\ Nayle Vilela LEITE ${ }^{1}$, Michelle Bafutto Gomes COSTA ${ }^{1}$, \\ Enio Chaves de OLIVEIRA $^{3}$ and Joffre RESENDE-FILHO ${ }^{1}$
}

\begin{abstract}
Context - Irritable bowel syndrome (IBS) is a functional bowel disease characterized by abdominal pain and altered intestinal habits. The pathophysiology of IBS remains unclear. Recent studies have demonstrated that some IBS patients, especially in diarrhea-predominant IBS (IBS-D), display persistent signs of minor mucosal inflammation and a modified intestinal microflora. The mesalazine has known intestinal anti-inflammatory properties. Saccharomyces boulardii is a probiotic used for a long time in treatment of diarrhea, including infectious diarrhea. Objective - Evaluate the effects of mesalazine alone, combined therapy of mesalazine with liophylised Saccharomyces boulardii or alone on symptoms of IBS-D patients. Methods - Based on Rome III criteria, 53 IBS-D patients (18 year or more) were included. To exclude organic diseases all patients underwent colonoscopy, stool culture, serum anti-endomisium antibody, lactose tolerance test and ova and parasite exam. Patients were divided in three groups: mesalazine group (MG) - 20 patients received mesalazine $800 \mathrm{mg}$ t.i.d. for 30 days; mesalazine and Saccharomyces boulardii group (MSbG) - 21 patients received mesalazine $800 \mathrm{mg}$ t.i.d. and Saccharomyces boulardii $200 \mathrm{mg}$ t.i.d. for 30 days and; Saccharomyces boulardii group (SbG) - 12 patients received Sb $200 \mathrm{mg}$ t.i.d. for 30 days. Drugs that might have any effect on intestinal motility or secretion were not allowed. Symptom evaluations at baseline and after treatment were performed by means of a 4-point likert scale including: stool frequency, stool form and consistency (Bristol scale), abdominal pain and distension. Paired $t$ test and Kruskal-Wallis test were used for statistical analyses. Results - Compared to baseline, there were statistically significant reduction of symptom score after 30 th day therapy in all three groups: MG $(P<0.0001)$; MSbG $(P<0.0001)$ and in SbG $(P=0.003)$. There were statistically significant differences in the symptom score at 30 th day therapy of the MG, MSbG and SbG groups $(P=0.03)$. There were no statistical differences between MSbG and MG symptom score at 30th day therapy $(P=0.9)$. Conclusions - The use of mesalazine alone, Saccharomyces boulardii alone or combined treatment with mesalasine and Saccaromyces boulardii improved IBS-D symptoms. The improvement of the symptom score was greater with mesalazine alone or combined with $\mathrm{Sb}$ as compared with $\mathrm{Sb}$ treatment alone. These preliminary results suggest that mezalazine may be useful in treatment of IBS-d patients, and warrant further larger studies.
\end{abstract}

HEADINGS - Irritable bowel syndrome. Diarrhea. Mesalamine. Saccharomyces boulardii.

\section{INTRODUCTION}

Irritable bowel syndrome (IBS) is a common, functional intestinal disorder that affects a heterogeneous group of patients. It is characterized by chronic and recurrent abdominal pain associated with altered bowel habits (Figure 1). From 10\%-20\% of adults have symptoms suggestive of IBS; prevalence is higher in women than in men and is equally prevalent all races as a function of race and geographic distribution ${ }^{(2)}$.

The pathophysiology of IBS remains unclear. Alterations in intestinal motor function, visceral hypersensitivity and gut-brain axis activity have been found in some patients with IBS. More recently, the presence of continuous mucosal inflammation and alterations in the intestinal microflora have been reported, particularly in diarrhea-predominant IBS (IBS-d). The putative role of immune cells, microflora and environmental factors (e.g. chronic stress), in the generation and perpetuation of this inflammatory process is not known. It has been suggested that interactions between intestinal flora and intestinal cells could produce intestinal inflammation in various gastrointestinal diseases and possibly in IBS. The imbalance between inhibiting factors of inflammatory response and antigenic stimuli could lead to the perpetuation of the inflammatory response ${ }^{(19,24,38,51)}$.

Since mucosal inflammation and imbalance in

Declared conflict of interest of all authors: non

Registro CEPHA Hospital Geral de Goiânia: 381/08

Study carried out at Instituto Goiano de Gastroenterologia, Goiânia, GO, Brasil.

${ }^{1}$ Instituto Goiano de Gastroenterologia, Goiânia, GO Brasil; 2 Disciplina de Gastroenterologia, Departamento de Clínica Médica, Faculdade de Medicina, Universidade

Federal de Goiás (UFGO), Goiânia, GO, Brasil; 'Departamento de Medicina Clínica, Faculdade de Medicina, Universidade Federal de Pernambuco (UFPE), Recife, PE,

Brasil; ' ${ }^{4}$ Departamento de Cirurgia, Faculdade de Medicina, Universidade Federal de Goiás (UFGO), Goiânia, GO, Brasil.

Correspondence: Mauro Bafutto. Rua 246, 25 - Setor Coimbra - 74535-170 - Goiânia, GO, Brasil. E-mail: maurobafutto@yahoo.com.br 
intestinal microflora might both play a role in IBS, it is reasonable to hypothesize that anti-inflammatory and/or probiotic agents would improve IBS symptoms. Mesalazine, a derivative of 5 - aminosalicylic acid, has intestinal antiinflammatory properties that are likely to be a function of topic exposure. It has been used in inflammatory bowel disease for many years. Recent reports showed good clinical results of mesalazine treatment in IBS patients ${ }^{(1,3)}$.

Saccharomyces boulardii, isolated from litchi fruit by Henri Boulard in the 1920s, belongs to the Saccharomyces genus, being commonly used in several food processes that produce beverages or require fermentation. This yeast is frequently prescribed in a lyophilized form as a biotherapeutic agent. Saccaromyces boulardii (S.boulardii) has been used in treatment of several intestinal diseases including $\operatorname{IBS}^{(5,21,28,29,45,49)}$.

Accordingly, the aim of this study was to assess the effects of mesalazine alone, combined therapy of mesalazine with $S$. boulardii or S. boulardii alone on IBS symptoms, through a small pilot study in IBS-D patients.

\section{METHODS}

\section{Ethical Considerations}

This study was approved by the Research Ethical Committee of Hospital Geral de Goiânia, and was done according to Helsinki Declaration. All patients gave their consent to participate.

A prospective study was realized with fifty-three (53) IBS-d patients (18 years old or more). Patients were included, based on the Rome III criteria (Figure 1 and 2). In order to exclude organic diseases, all patients were screened by colonoscopy, stool culture, serum anti endomysium antibody, lactose tolerance test and ova and parasite stool test.

Recurrent abdominal pain or discomfort** at least 3 days/month in the last 3 months associated with two or more of the following:

1. Improvement with defecation

2. Onset associated with a change in frequency of stool

3. Onset associated with a change in form (appearance) of stool

*Criterion fulfilled for the last 3 months with symptom onset at least 6 months prior to diagnosis

** "Discomfort" means an uncomfortable sensation not described as pain.

FIGURE 1. Diagnostic Criterion * for irritable bowel syndrome In pathophysiology research and clinical trials, a pain/discomfort frequency of at least 2 days a week during screening evaluation is recommended for subject eligibility.

\footnotetext{
1 IBS-C - hard or lump stolls a at least $25 \%$ and loose (mushy) or watery stools $\mathrm{b}<25 \%$ of bowel movements*

2. IBS-D - loose (mushy) or water stolls b at least $25 \%$ and hard or lumpy stool a $<25 \%$ of bowel movements*

3. IBS-M) - hard or lump stolls a at least $25 \%$ and loose (mushy) or watery stools $\mathrm{b}<25 \%$ of bowel movements*

4. Unsubtyped IBS - insufficient abnormality of stool consistency to meet for IBS-C D, or $\mathrm{M}^{*}$
}

FIGURE 2. Subtyping IBS by predominant stool pattern

IBS: irritable bowel syndrome; IBS-C: IBS with constipation; IBS-D: IBS with diarrhea; IBS-M: IBS mixed; *In the absence of antidiarrheal or laxative use

\section{Study Design}

Patients were stratified into one of three groups: 1) Mesalazine Group (MG) - 20 patients received mesalazine (M) $800 \mathrm{mg}$ three times a day (t.i.d.) for 30 days; 2) Mesalazine and S. boulardii Group (MSbG) - 21 patients received M 800 $\mathrm{mg}$ t.i.d. and $S$. boulardii $(\mathrm{Sb}) 200 \mathrm{mg}$ t.i.d. for 30 days; and 3) S. boulardii Group (SbG) - 12 patients received Sb 200 $\mathrm{mg}$ t.i.d. for 30 days. Drugs that influence intestinal motility or secretion were not allowed.

Symptom evaluation at baseline and after treatment was performed by means of a 4 point likert scale assessing: stool frequency, stool form and consistency (based on Bristol Scale), abdominal pain and abdominal distension (table 1).

The differences between symptom scores at baseline and after treatment were compared using paired $t$ test and Kruskal-Wallis test for statistical analyses.

TABLE 1 . The symptom score evaluation submitted to all of tree groups of avaliated patients before and after 30 days of therapy ( $\min$ score $=4$, $\max$ score $=16$ )

\begin{tabular}{lcccc}
\hline & \multicolumn{5}{c}{ Symptom Score } \\
& 1 & 2 & 3 & 4 \\
\hline $\begin{array}{l}\text { 1. Stool frequency } \\
\text { 2. Stool form and } \\
\text { consistency }\end{array}$ & $<4$ & 3 & 4 a 5 & $>5$ \\
$\begin{array}{l}\text { 3. Abdominal pain } \\
\begin{array}{l}\text { 4. Abdominal } \\
\text { distension }\end{array}\end{array}$ & Absent & Mild & Moderate & Severe \\
\hline
\end{tabular}

\section{RESULTS}

Demographic data and symptom characterization at baseline are in table 2. As compared to baseline, statistically significant improvements in symptoms score were seen at the 30 th day therapy for the MG, $(P<0.0001)$, MSbG

TABLE 2. Patient demographic data and symptom score at baseline

\begin{tabular}{lccc}
\hline & Mesalazine & $\begin{array}{c}\text { Mesalazine and } \\
\text { Saccharomyces }\end{array}$ & Saccharomyces \\
\hline Age (year) & 46 & 50 & 43 \\
Male & 7 & 7 & 4 \\
Female & 13 & 14 & 8 \\
$\begin{array}{l}\text { Symptom score } \\
\text { Mean (SD) }\end{array}$ & $10.70(2.34)$ & $10.67(2.67)$ & $9.75(1.54)$ \\
Total & 20 & 21 & 12 \\
\hline
\end{tabular}


$(P<0.0001)$, and $\mathrm{SbG}(P=0.003)$ groups (figures 3,4 and 5 respectively). Significant differences were also seen after one month when comparing GM, GMSb and GSb $(P=0.03)$ (figure 6). No significant differences were seen between GMSb and GM $(P=0.9)$.

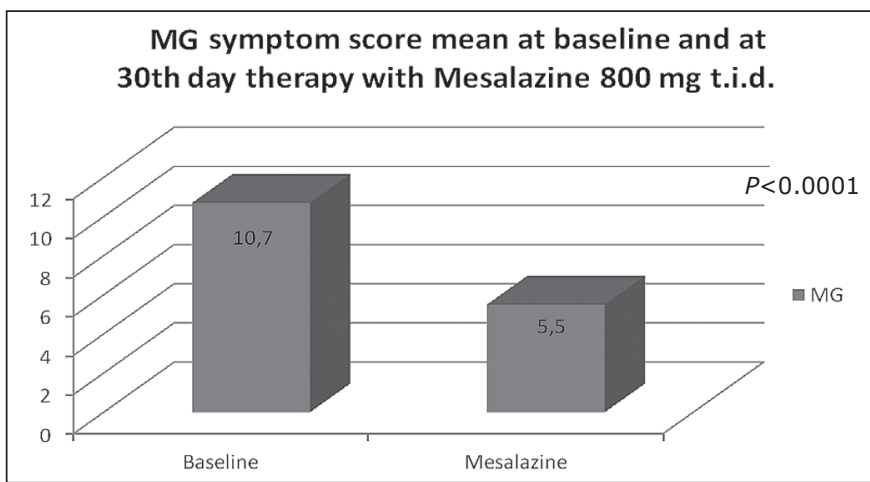

FIGURE 3. Mesalazine group (MG) symptom score mean at baseline (SD: $\pm 2,34)$ and at 30 th day (SD: $\pm 2,89)$ therapy with mesalazine $(\min$ score $=4 ; \max$ score $=16)$

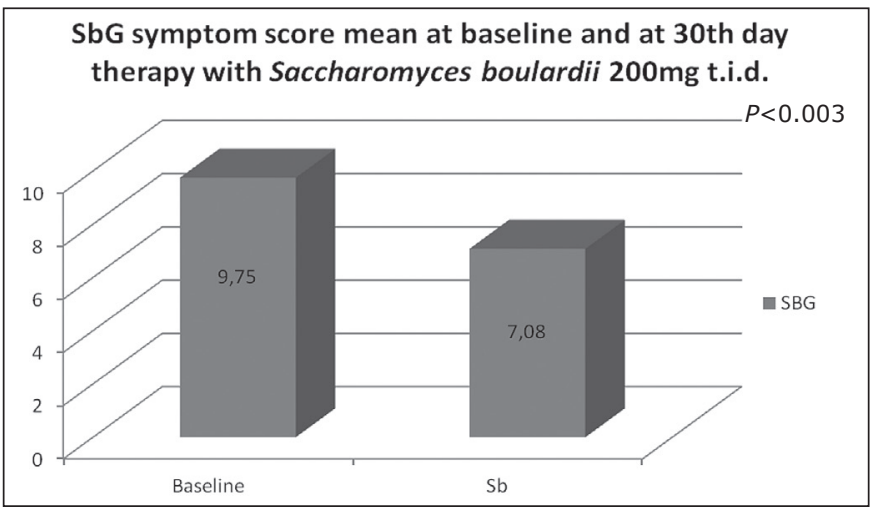

FIGURE 4. Saccharomyces boulardii group ( $\mathrm{SbG}$ ) symptom score mean at baseline (SD: $\pm 1,54)$ and at 30 th day $(\mathrm{SD}: \pm 2,64)$ therapy with $S$. boulardii $(\min$ score $=4 ;$ max score $=16)$

Sb: Saccharomyces boulardii

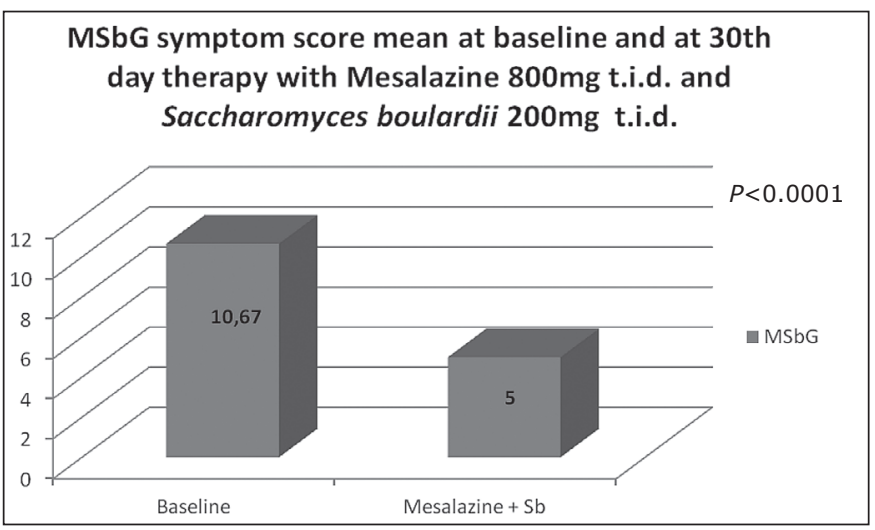

FIGURE 5. Mesalazine and Saccharomyces boulardii group (MSbG) symptom score mean at baseline (SD: $\pm 2,37)$ and at 30 th day (SD: $\pm 1,9)$ therapy with mesalazine and $S$. boulardii ( $\min$ score $=4$; $\max$ score $=16)$

SB: Saccharomyces boulardii
Results of Groups Msb, M and Sb Symptom score mean at 30th day of therapy

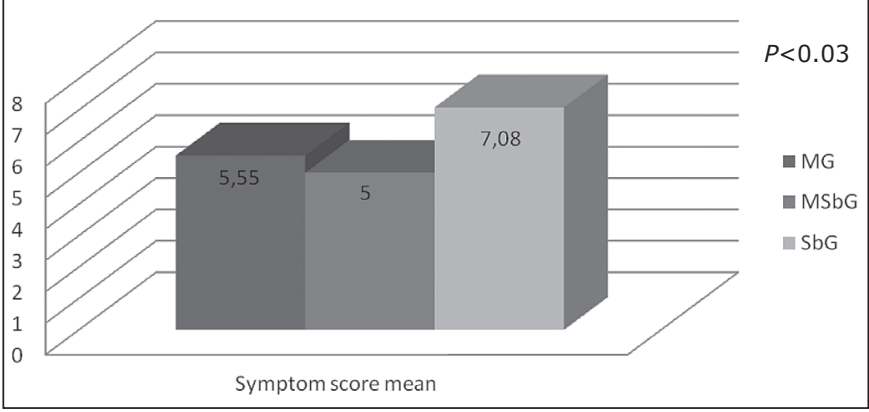

FIGURE 6. Results of MSbG, MG and SbG score mean after 30 th day of therapy $(\min$ score $=4$; $\max$ score $=16)$

MSb: mesalazine and S. boulardii; M: mesalazine; Sb: Saccharomyces boulardii

\section{DISCUSSION}

IBS is a complex and variable disorder where prominent symptoms include abdominal pain and altered bowel function, manifested by diarrhea, constipation, a sensation of fullness following evacuation, as well as fecal mucous discharge. No physical or laboratory findings are specific for IBS, and the diagnosis is, therefore, based on symptomatology ${ }^{(1)}$.

A unifying hypothesis to explain the pathogenesis of IBS remains elusive. Alterations in gastrointestinal motor function, enhanced visceral perception of painful stimuli and psychosocial factors are considered as key contributors to symptom generation in $\operatorname{IBS}^{(2,23)}$. Factors that are receiving recent attention include reduced ability to expel intestinal gas, altered central processing of afferent signals and intestinal inflammation. While routinely performed, histologic examination typically reveals no significant colonic or mucosal abnormalities in the majority of the patients, although quantitative histological, immunohistochemical and ultrastructural analyses sometimes provide evidence of subtle morphologic changes in these patients ${ }^{(2)}$.

Numerous studies performed mucosal biopsies in Post infective (PI)-IBS and IBS-D, and found increased number of CD3+ lymphocytes. Although discrepancies in findings exist, this increase in CD3+ lymphocytes is consistently reported. Also shown were increases in CD25+ lymphocytes, indicating the presence interleukin (IL)-2 receptor, a marker of activated lymphocytes ${ }^{(11)}$. In addition, studies have examined the presence of mRNA for IL-1 $\beta$, a macrophage product that has been shown to be increased in both Post infective PI-IBS and IBS-D. These inflammatory cells produce cytokines, which are known to alter enteric neural function and contribute to diarrheal symptoms $\mathrm{s}^{(8,20,22,56)}$.

The gut has its permeability increased in the presence of inflammatory cytokines, as well as in the context of bacterial gastroenteritis and in PI-IBS and IBS-D ${ }^{(17)}$. The lamina propria, as well as surface and crypt epithelium have been shown to contain increased numbers of T-lymphocytes in 
IBS; the predominant form of diarrhea in IBS is associated with a greater increase in mucosal T-lymphocytes, relative to the predominant form of constipation ${ }^{(12,16,50,54)}$.

Increased numbers of nerve fibres staining positively for neuron specific enolase, substance P and 5-HT (but not calcitonin gene-related peptide) have been demonstrated in biopsies from the terminal ileum and rectosigmoid in patients with both PI-and non-PI-IBS. In addition, positively stained nerve fibres around mast cells are reported to be significantly increased in density in IBS patients compared to controls ${ }^{(58)}$.

The role of mast cells (MC) has also been investigated in a number of studies ${ }^{(15,23,39,42,60)}$. In the gastrointestinal tract, as in other mucosal surfaces, MC are part of the allergic response to luminal antigens and of protective, innate immune responses. Increased number of MC, as well as increased concentration of its products, has been described in the terminal ileum and the proximal and distal colon of IBS patients ${ }^{(3,39,60)}$.

These findings, associated with increased mast cell degranulation, increased spontaneous release of $\mathrm{MC}$ tryptase and histamine 1 and increased proximity of $\mathrm{MC}$ to enteric nerves in IBS, suggest a role for $\mathrm{MC}$ in the disturbed, sensorimotor function characteristic of this condition ${ }^{(3,16,26,39,40,41,58)}$. The proximity of $\mathrm{MC}$ to enteric nerves suggests that MC mediators have increased potential to activate enteric neurons ${ }^{(39)}$.

$\mathrm{MC}$ are also of importance as end effectors of the braingut axis (BGA). Upon activation of the BGA by stress, MC releases a wide range of neurotransmitters and other proinflammatory molecules. These mediators include histamine, heparin, chondroitin sulfate, chymase, carboxypeptidase, tryptase, platelet activating factor, prostaglandin (PGD2), leukotriene (LTC4) and a variety of interleukins such as IL1b, IL-3, IL-4, IL-5, IL-6, IL-8, IL-9, IL-10, IL-13, IL-16, IL-18, IL-25, TNF-alpha, granulocyte-macrophage colonystimulating factor (GM-CSF), stem cell factors, macrophage chemotactic peptide (MCP)-1, 3\&4, regulated on activation of normal T cell-expressed and secreted protein (RANTES), and eotaxin ${ }^{(25)}$.

Finally, MC are of importance translating stress signals into release of pro-inflammatory mediators that can stimulate gastrointestinal nerve endings and affect its perception, change intestinal motility, and cause intestinal hyperpermeability ${ }^{(4,52)}$. Accordingly, MC dysfunctions may be associated with the key symptoms (abdominal pain and/or discomfort and altered intestinal habit) of IBS.

Mesalazine has anti-inflammatory properties and is used in the treatment of inflammatory bowel diseases. Although the exact mechanism of action of mesalazine has still to be elucidated, several potential mechanisms have been suggested, including 5-aminosalicylate-induced inhibition of inflammation by interfering with the metabolism of arachidonic acid, prevention of mucosal generation of leukotrienes and prostaglandins, scavenging of free radicals and mechanisms only recently identified involving inhibition of nuclear factor-kappaB $(\mathrm{NF \kappa B})$ and induction of apoptosis ${ }^{(6,18,31,43,47,48,55,57,59)}$. Additional relevant properties include changes in the production of immune globulins and diminished production of interleukin-1 and partial inhibition of platelet activating factor (PAF) expression, resulting in a decrease in leucocyte trafficking ${ }^{(32)}$. Moreover there is evidence that mesalazine has a potential inhibition on MC histamine release and was effective to reduce MC infiltration in patients with $\operatorname{IBS}^{(13,19)}$.

Interactions between the intestinal flora and intestinal cells have been identified as determinants of production of intestinal inflammation in various gastrointestinal diseases and possibly in IBS. The imbalance between inhibiting factors of inflammatory response and antigenic stimuli could lead to the perpetuation of the inflammatory response ${ }^{(50)}$. Based on these points, several probiotics have been used in IBS.

$S$. boulardii influences the transit of micro-organism in the gastrointestinal tract, being a probiotic agent. During the intestinal transit, $S$. boulardii interacts with resident microflora and intestinal mucosa. Moreover, experimental studies suggest that $S$. boulardii is protective against enteric pathogens, modulating the host immune response, decreasing inflammation and hydro electrolytic secretions, inhibiting bacterial toxin and enhancing trophic factors such as brush border membrane enzymes and nutrient

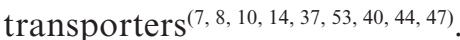

Controlled clinical trials suggested that oral administration of $S$. boulardii could treat or prevent gastrointestinal diseases such as antibiotic-associated diarrhea, recurrent Clostridium difficile associated diseases, traveler's diarrhea, children acute diarrhea, enteral tube feeding-associated diarrhea, AIDS-associated diarrhea, intestinal bowel disease such as Crohn's disease and ulcerative colitis and IBS $^{(4,20,22,27,30,33,34,35,46)}$. In IBS a double-blind, placebocontrolled study conducted in 34 patients with diarrhea, treatment with $S$. boulardii decreased the daily number of stools $(P<0.05)$ and improved their consistency $(P<0.05)^{(33)}$.

In the current study, we focused on the putative participation of microbial, intestinal inflammation or both, in IBS. Accordingly, we used two drugs, mesalazine and/ or Saccharomyces boulardii that may be synergistic. While there are some evidence to support the use of mesalazine or S.boulardii alone, the treatment of mesalazine associated with S.boulardii in IBS-d patients is lacking.

We found significant improvement in symptoms in the three groups. Nonetheless, we highlight that the placebo effect is relevant in IBS, with a magnitude ranging from $20 \%$ to more than $50 \%$ in some trials ${ }^{(9,36)}$. Other limitations of this study are the small number of patients and the followup period of 30 days.

There were no statistical difference between the groups that used mesalazine, but we observed a significant reduction on symptom score when compared groups that used mesalazine to $S$. boulardii alone. It is important to note that mesalazine was not compared to placebo, but with $S$. boular$d i i$, an effective agent in the treatment of IBS-d. Accordingly, we conclude that mesalazine improved key symptoms and has therapeutic properties in IBS-d. These preliminary results warrant further, larger, controlled studies. 
Bafutto M, Almeida JR, Leite NV, Costa MBG, Oliveira EC, Resende Filho J. Tratamento da síndrome do intestino irritável tipo diarreia-predominante com mesalazina e/ou Saccharomyces boulardii. Arq Gastroenterol. 2013,50(4):304-9.

RESUMO - Contexto - A síndrome do intestino irritável (SII) é uma doença funcional do intestino, caracterizada por dor abdominal e alterações do hábito intestinal, cuja fisiopatologia permanece desconhecida. Estudos recentes sustentam a hipótese de que algumas formas de SII, especialmente a síndrome do intestino irritável tipo diarreia (SII-D), apresentam sinais de uma inflamação de baixo grau persistente da mucosa intestinal e alterações da microflora intestinal. A mesalazina é conhecida por suas propriedades anti-inflamatórias intestinais. O Saccharomyces boulardii é um probiótico largamente utilizado para o tratamento da diarreia relacionada à causa infecciosa. Objetivo - Avaliar os efeitos da mesalazina, da terapia com mesalazina combinada ao Saccharomyces boulardii e do Saccharomyces boulardii, em pacientes com SII-D. Método - Com base nos critérios de Roma III, 53 pacientes com SII-D (maiores de 18 anos) foram incluídos. Para excluir as doenças orgânicas, todos os pacientes realizaram colonoscopia, coprocultura, anticorpo anti-endomísio, teste de tolerância à lactose e exame parasitológico de fezes. Os pacientes foram divididos em três grupos: grupo mesalazina (GM) - 20 pacientes foram medicados com mesalazina via oral $800 \mathrm{mg}$ t.i.d. por 30 dias; grupo mesalazina e Saccharomyces boulardii (GMSb) - 21 pacientes foram medicados com mesalazina 800mg t.i.d. e Saccharomyces boulardii $200 \mathrm{mg}$ via oral t.i.d. por 30 dias; grupo Saccharomyces boulardii (GSb) - 12 pacientes foram medicados com Saccharomyces boulardii $200 \mathrm{mg}$ t.i.d. por 30 dias. Não foram permitidas drogas concomitantes com algum efeito sobre secreção ou motilidade intestinal. Os sintomas foram avaliados no basal e após tratamento por meio da escala de Likert de 4 pontos que incluía: frequência de evacuações; forma e consistência das fezes (baseado na escala de Bristol); dor abdominal; e distensão abdominal. A analise estatística foi realizada por meio de teste $t$ pareado e do teste de Kruskal-Wallis. Resultados - Comparados ao basal, observou-se uma redução estatisticamente significativa da pontuação de sintomas após 30 dias de tratamento no GM $(P<0.0001)$; GMSb $(P<0.0001)$; e GSb $(P<0.003)$. Diferença estatisticamente significativa da pontuação de sintomas após 30 dias de tratamento entre GM, GMSb e GSb $(P=0.03)$. Não foi observada diferença estatisticamente significativa entre GM e GMSb após 30 dias de tratamento $(P=0,9)$. Conclusão - O uso da mesalazina isolada, do Saccharomyces boulardii isolado ou do tratamento combinado com ambos, mesalazina e Saccaromyces boulardii, melhoraram os sintomas da SII-D. A melhora dos sintomas foi maior naqueles que usaram mesalazina seja isolada ou em combinação com Saccharomyces boulardii quando comparada com o uso de Saccharomyces boulardii isoladamente. Estes resultados sugerem que a mesalazina pode ser útil no tratamento de pacientes com SII-D e justificam outros estudos com maior número de pacientes.

DESCRITORES - Síndrome do intestino irritável. Diarreia. Mesalamina. Saccharomyces boulardii.

\section{REFERENCES}

1. Bafutto M, Almeida JR, Leite VN, Oliveira EC, Gabriel-Neto S, Rezende-Filho J. Treatment of postinfectious irritable bowel syndrome and noninfective irritable bowel syndrome with mesalazine. Arq gastroenterol. 2011;48:36-40.

2. Barbara G, De Giorgio R, Stanghellini V, Cremon C, Salvioli B, Corinaldes R. New pathophysiological mechanisms in irritable bowel syndrome. Aliment Pharmacol Ther. 2004;20 (Suppl 2):1-9.

3. Barbara G, Stanghellini V, De Giorgio R, Cremon C, Cottrell GS, Santini D, Pasquinelli G, Morselli-Labate AM, Grady EF, Bunnett NW, Collins SM, Corinaldesi R. Activated mast cells in proximity to colonic nerves correlate with abdominal pain in irritable bowel syndrome. Gastroenterology. 2004;126:693-702.

4. Bercik P, Verdu EF, Collins SM. Is irritable bowel syndrome a low-grade inflammatory bowel disease? Gastroenterol Clin N Am. 2005;34:235-45.

5. Bleichner G, Bléhaut H, Mentec H, Moyse D. Saccharomyces boulardii prevents diarrhea in critically ill tube-fed patients. A multicenter, randomized, double-blind placebo-controlled trial. Intensive Care Med. 1997;23,517-23.

6. Bus PJ, Nagtegaal ID, Verspaget HW, Lamers CB, Geldof H, Van Krieken JH, Griffioen G. Mesalazine-induced apoptosis of colorectal cancer: on the verge of a new chemopreventive era? Aliment Pharmacol Ther. 1999;13:1397-402.

7. Buts JP, Bernasconi P, Van Craynest M P, Maldague P, De Meyer R. Response of human and rat small intestinal mucosa to oral administration of Saccharomyces boulardii. Pediatr Res. 1986;20,192-6.

8. Buts JP, De Keyser N, De Raedemaeker L. Saccharomyces boulardii enhances rat intestinal enzyme expression by endoluminal release of polyamines. Pediatr Res. 1994;36,522-7.

9. Camilleri M, Mayer EA, Drossman DA, Heath A, Dukes GE, McSorley D, Kong S, Mangel AW, Northcutt AR. Improvement of pain and bowel function in female irritable bowel patients with alosetron, a 5-HT3 receptor antagonist. Aliment Pharmacol Ther. 1999;13:1149-59.

10. Castagliuolo I, Riegler MF, Valenick L, LaMont JT, Pothoulakis C. Saccharomyces boulardii protease inhibits the effects of Clostridium difficile toxins A and B in human colonic mucosa. Infect Immun. 1999;67:302-7.

11. Chadwick VS, Chen W, Shu D, Paulus B, Bethwaite P, Tie A, Wilson I. Activation of the mucosal immune system in irritable bowel syndrome. Gastroenterology. 2002; 122:1778-183.
12. Corinaldezi R, Stranghellini V, Cremon C, Gargano L, Cogliandro RF, De Giorgio R, Bartesaghi G, Canovi B, Barbara G. Effect of mesalazine on mucosal immune biomarkers in irritable bowel syndrome: a randomized controlled proof-of-concept study. Aliment Pharmacol Ther. 2009;30:245-52.

13. Cremon C, Gargano L, Morselli-Labate AM, Santini D, Cogliandro RF, De Giorgio R, Stanghellini V, Corinaldesi R, Barbara G. Mucosal Immune Activation in Irritable Bowel Syndrome: Gender-Dependence and Association With Digestive Symptoms. Am J Gastroenterol. 2009;104:392-400.

14. Czerucka D, Dahan S, Mograbi B, Rossi B, Rampal P. Saccharomyces boulardii preserves the barrier function and modulates the signal transduction pathway induced in enteropathogenic Escherichia coli-infected T84 cells. Infect Immun. 2000;68,5998-6004

15. Dunlop SP, Jenkins D, Nela KR, Spiller RC. Relative importance of enterochoromaffin cell hyperplasia, anxiety, and depression in postinfectious IBS. Gastroenterology. 2003;125:1651-9.

16. Dunlop SP, Jenkins D, Spiller RC. Distinctive clinical, psychological, and histological features of postinfective irritable bowel syndrome. Am J Gastroenterol. 2003;98:1578-83

17. Dunlop SP, Hebden JM, Naesdal J, Olbe L, Perkins AC, Spiller RC. Abnormal intestinal permeability in subgroups of diarrhoea predominant irritable bowe syndromes. Am J Gastroenterol. 2006;101:1288-94.

18. Forbes A, Cartwright A, Marchant S, McIntyre P, Newton M. Review article: Oral, modified-release mesalazine formulations-proprietary versus generic. Aliment Pharmacol Ther. 2003;17:1207-14

19. Fox CC, Moore WC, Lichtenstein LM. Modulation of mediator release from human intestinal mast cells by sulfasalazine and 5-aminosalicylic acid. Dig Dis Sci. 1991;36:179-84

20. Galeazzi F, Haapala EM, van Rooijen N, Vallance BA, Collins SM. Inflammation-induced impairment of enteric nerve function in nematode-infected mice is macrophage dependent. Am J Physiol Gastrointest Liver Physiol. 2000;278:G259-65.

21. Guslandi M, Mezzi G, Sorghi M, Testoni PA. Saccharomyces boulardii in maintenance treatment of Crohn's disease. Dig Dis Sci. 2000;45: 1462-4.

22. Guslandi M, Giollo P, Testoni PA. A pilot trial of Saccharomyces boulardii in ulcerative colitis. Eur J Gastroenterol Hepatol. 2003;15:697-8.

23. Gwee KA, Leong YL, Graham C, McKendrick MW, Collins SM, Walters SJ, Underwood J, Read N. The role of psychological and biological factors in postinfective gut dysfunction. Gut. 1999;44:400-6. 
24. Gwee KA, Collins SM, Read NW, Rajnakova A, Deng Y, Graham JC, McKendrick MW, Moochhala SM. Increased rectal mucosal expression of interleukin lbeta in recently acquired post-infectious irritable bowel syndrome. Gut. 2003;52:523-6.

25. He SH. Key role of mast cells and their major secretory products in inflammatory bowel disease. World J Gastroenterol. 2004;10:309-18.

26. Hiatt RB, Katz L. Mast cells in inflammatory conditions of the gastrointestinal tract. Am J Gastroenterol. 1962;37:541-5.

27. Horwitz BJ, Fisher RS. The irritable bowel syndrome. N Engl J Med. 2001;344:1846-50.

28. Htwe K, Yee KS, Tin M, Vandenplas Y. Effect of Saccharomyces boulardii in the Treatment of Acute Watery Diarrhea in Myanmar Children: A Randomized Controlled Study. Am J Trop Med Hyg. 2008;78,214-6.

29. Klein SM, Elmer GW, McFarland LV, Surawicz CM, Levy RH. Recovery and elimination of the biotherapeutic agent, Saccharomyces boulardii, in healthy human volunteers. Pharm Res. 1993;10:1615-9.

30. Kotowska, M., Albrecht, P., and Szajewska, H. Saccharomyces boulardii in the prevention of antibiotic-associated diarrhoea in children: a randomized double-blind placebo-controlled trial. Aliment Pharmacol Ther. 2005;21:583-90.

31. Liptay S, Bachem M, Hacker G, Adler G, Debatin KM, Schmid RM. Inhibition of nuclear factor kappa B and induction of apoptosis in T-lymphocytes by sulfasalazine. Br J Pharmacol. 1999;128:1361-9.

32. MacDermott RP. Progress in understanding the mechanisms of action of 5-aminosalicylic acid. Am J Gastroenterol. 2000;95:3343-5.

33. Maupas J, Champemont P, Delforge M. Treatment of irritable bowel syndrome with Saccharomyces boulardii: a double-blind, placebo-controlled-study. Med Chir Dig. 1983;12:77-9.

34. McFarland LV. Meta-analysis of probiotics for the prevention of antibiotic associated diarrhea and the treatment of Clostridium difficile disease. Am J Gastroenterol. 2006;101:812-22.

35. McFarland LV. Meta-analysis of probiotics for the prevention of traveler's diarrhea. Travel Med Infect Dis. 2007;5:97-105

36. Muller-Lissner SA, Fumagalli I, Bardhan KD, Pace F, Pecher E, Nault B, Rüegg P. Tegaserod, a 5-HT(4) receptor partial agonist, relieves symptoms in irritable bowel syndrome patients with abdominal pain, bloating and constipation. Aliment Pharmacol Ther. 2001;15:1655-66.

37. Mumy KL, Chen X, Kelly CP, McCormick BA. Saccharomyces boulardii interferes with Shigella pathogenesis by post-invasion signaling events. Am J Physiol Gastrointest Liver Physiol. 2007;294:G599-609.

38. Murray CD, Flynn J, Ratcliffe L, Jacyna MR, Kamm MA, Emmanuel AV. Effect of acute physical and psychological stress on gut autonomic innervation in irritable bowel syndrome. Gastroenterology. 2004;127:1695-703.

39. O’Sullivan M, Clayton N, Breslin NP, Harman I, Bountra C, McLaren A, O'Morain CA. Increased mast cells in the irritable bowel syndrome. Neurogastroenterol Motil. 2000;12:449-57.

40. Ozkan TB, Sahin E, Erdemir G, Budak F. Effect of Saccharomyces boulardii in children with acute gastroenteritis and its relationship to the immune response. J Int Med Res. 2007;35:201-12

41. Park CH, Joo YE, Chosi SK, Rew JS, Kim SJ, Lee MC. Acitivated mast cells infiltrate in close proximity to enteric nerves in diarrhea-predominant irritable bowel syndrome. J Korean Med Sci. 2003;18:204-10.

42. Park JH, Rhee PL, Kim G, Lee JH, Kim YH, Kim JJ, Rhee JC, Song SY. Enteroendocrine cell counts correlate with visceral hypersensitivity in patients with diarrhoea-predominant irritable bowel syndrome. Neurogastroenterol Motil. 2006;18:539-46.
43. Reinacher-Schick A, Seidensticker F, Petrasch S, Reiser M, Philippou S, Theegarten D, Freitag G, Schmiegel W. Mesalazine changes apoptosis and proliferation in normal mucosa of patients with sporadic polyps of the large bowel. Endoscopy. 2000;32:245-54.

44. Rodrigues AC, Cara DC, Fretez SH, Cunha FQ, Vieira EC, Nicoli JR, Vieira LQ. Saccharomyces boulardii stimulates sIgA production and the phagocytic system of gnotobiotic mice. J Appl Microbiol. 2000;89:404-14.

45. Saint-Marc T, Rossello-Prats L, Touraine JL Efficacy of Saccharomyces boulardii in the treatment of diarrhea in AIDS. Ann Med Interne. 1991;142:64-65.

46. Salzmann JL, Peltier-Koch F, Bloch F, Petite JP, Camilleri JP. Morphometric study of colonic biopsies: a new method of estimating inflammatory diseases. Lab Invest. 1989;60:847-51

47. Sandborn W J, Hanauer SB. Systematic review: the pharmacokinetic profiles of oral mesalazine formulations and mesalazine pro-drugs used in the management of ulcerative colitis. Aliment Pharmacol Ther. 2003;17:29-42.

48. Small RE, Schraa CC. Chemistry, pharmacology, pharmacokinetics, and clinica applications of mesalamine for the treatment of inflammatory bowel disease. Pharmacotherapy. 1994;14:385-98.

49. Sougioultzis S, Simeonidis S, Bhaskar K R, Chen X, Anton PM, Keates S, Pothoulakis C, Kelly CP. Saccharomyces boulardii produces a soluble anti-inflammatory factor that inhibits NF-kappaB-mediated IL-8 gene expression. Biochem Biophys Res Commun. 2006;343:69-76.

50. Spiller RC, Jenkisn D, Thornley JP, Hebden J, Wright T, Skinner M, Neal K Increased rectal mucosal enteroendocrine cells, T lymphcytes, and increased gut permeability following acute Campylobacter enteritis and in post-dysenteric irritable bowel syndrome. Gut 2000;47:804-11.

51. Stead RH, Dixon MF, Bramwell NH, Riddell RH, Bienenstock J. Mast cells are closely apposed to nerves in the human gastrointestinal mucosa. Gastroenterology. 1989;97:575-85.

52. Talley NJ, Spiller R. Irritable bowel syndrome: a little understood organic bowel disease? Lancet. 2002;360:555-64.

53. Tasteyre A, Barc MC, Karjalainen T, Bourlioux P, Collignon A. Inhibition of in vitro cell adherence of Clostridium difficile by Saccharomyces boulardii. Microb Pathog. 2002;32:219-25.

54. Tornblom H, Lindberg G, Nyberg B, Veress B. Full-thickness biopsy of the jejunum reveals inflammation and enteric neuropathy in irritable bowel syndrome. Gastroenterology. 2002;123:1972-9.

55. Tromm A, Griga T, May B. Oral mesalazine for the treatment of Crohn's disease: clinical efficacy with respect to pharmacokinetic properties. Hepatogastroenterol 1999;46:3124-35.

56. Xia Y, Hu HZ, Liu S, rean J, Zafirov DH, Wood JD. IL-1beta and IL-6 excite neurons and suppress nicotinic and noradrenergic neurotransmission in guinea pig enteric nervous system. J Clin Invest. 1999;103:1309-16.

57. Wahl C, Liptay S, Adler G, Schmid RM. Sulfasalazine: a potent and specific inhibitor of nuclear factor kappa B. J Clin Invest. 1998;101:1163-74.

58. Wang LH, Fang XC, Pan GZ. Bacillary dysentery as a causative factor of irritable syndrome and its pathogenesis. Gut. 2004;53:1096-101.

59. Weber CK, Liptay S, Wirth T, Adler G, Schmid RM. Suppression of NF-kappaB activity by sulfasalazine is mediated by direct inhibition of IkappaB kinases alpha and beta. Gastroenterology. 2000;119:1209-18.

60. Weston AP, Biddle WL, Bhatia PS, Miner Jr PB. Terminal ileal mucosal mast cells in irritable bowel syndrome. Neurogastroenterol Motil. 2000;12:449-57.

Received 13/12/2012 Accepted 25/6/2013 